\title{
DEVELOPMENT OF THE CONCEPT OF SOLID WASTE MANAGEMENT IN THE TOURISM INDUSTRY OF THE KALININGRAD REGION
}

\author{
MARINA SEMERYAKOVA
}

Immanuel Kant Baltic Federal University, Institute of Nature Management, Regional Development and Urban Planning, IKBFU, 236040, Alexander Nevsky str., 14, Kaliningrad, Russia

e-mail: MSemeryakova@stud.kantiana.ru

\section{JEL CODE \\ KEYWORDS}

ABSTRACT
Z32

geo-ecological problems of solid household waste, location of landfills, the waste management system

The article presents an overview of the treatment of municipal solid waste in the tourism industry of the Kaliningrad region and the analysis of environmental problems of disposal. The aim of the article is to show the features of the modern state of the sphere of waste management and its impact on the tourist attractiveness of the region.

The author reveals the material composition, the classes of hazard and the spatial distribution of household waste, and defines their relationship with the municipal districts and tourist centers of the region. In the article is shown the mechanism of solid waste management in the tourism industry of the Kaliningrad region based on the analysis of the environmental situation, finding ways for the use of external opportunities taking into account the nature of the location of tourist centers and situation of the region. The Kaliningrad region has an exclave position and is separated from the main territory of the country, which is a big problem in terms of disposal. Strategic waste management planning relies on a set of laws and procedures, the use of which will ensure a rapid response to the increase in the amount of waste, including plastic. To solve this problem, the author proposes to use a positive foreign experience, given domestic regulatory framework. The situation analysis of the mutual influence of tourism and the ecological status of municipal solid waste in the region allows us to formulate recommendations for the greening of tourism as a factor of regional development on the basis of trends in world practice of waste issues and requirements of modernity.

\section{Introduction}

The rapid formation of large amounts of waste is a concern not only of the European Union. The interaction of tourism and environment is closely connected with the problem of sustainable development of the region. The main factors affecting the flow of solid waste are a permanent population and number of tourists. One of the main conditions of sustainable development of the concept of the United Nations is greening of all production types (including in services). European countries are 
an example of the "principle of sustainable tourism". The European Union believes that a clean environment is a basic condition of everything else and the basic condition of development of the tourism industry in the regions. All around the world there is exercised a practice to minimize the amount of waste sent to processing facilities and disposal, decided on the basis of inclusion in the scheme of solid waste management and allocation of resources, suitable for further use (Antmann, Celik, Shi, Dai, 2012). Legislative initiative for the creation of solid waste management systems in Russia are declarative.

Unlike European practice, Russia's approach is to improve waste management.

Solid waste disposal in the region does not take into account the criteria of resource saving and environmental safety. The region has no strategic approach to waste management, there is no scientifically based concept and strategy for solving the problem of solid waste, nor recycled materials used. Due to the difficult environmental situation in the landfills there is a need of transition to full recycling.

The aim of this work is to develop a regional concept of solid waste management in the tourist zone of the Kaliningrad region.

Objective: to develop optimal systems for their collection and disposal (transport).

Integrated solid waste management includes the organization of collection, removal (transportation), processing and disposal, and the implementation of measures to reduce the quantity of waste sent for recycling and disposal.

The basis of the proposed concept is:

a) various approaches to the treatment of different components of household waste;

b) integrated use of the regulators (legal, economic, organizational, managerial, technological and educational).

The object of research are methods of disposal of solid waste and the legal framework of waste management. Because of the difficult ecological situation of the landfills there is a need of transition to full recycling.

\section{Research methods}

The study is based on the complex of general scientific methods: abstract-logical, analysis, synthesis, systemic method. Methods of special branches of science have been used: comparative legal and statistical. The paper presents an attempt to develop a unified model that combines social, economic and environmental aspects of the research subject.

Integrated solid waste management includes the organization of their collection, removal, processing and disposal, and implementation of measures to reduce the amount of waste sent to recycling and disposal.

The concept is to apply various approaches to the management of different components of household waste and integrated use of the regulators (legal, economic, organizational, managerial, technological and educational). 
The goal was achieved by studies in the evaluation literature on the subjects in the field of ecology, tourism, and Internet resources. Estimated was the total volume of waste production and consumption in the Kaliningrad region. As a source of information to estimate the volume of waste production and consumption patterns and their future changes various sources were used: data of the Federal Statistical Observation No. 2-TP (waste); details of regional cadastre of production and consumption waste in the Kaliningrad region; data of administrations of municipal entities and specialized organizations dealing with waste management in the Kaliningrad region; data from the Kaliningrad regional customs.

\section{Analytical assessment of the recycling of solid waste in the tourism industry in the Kaliningrad region}

Reduction of environmental comfort has a negative impact on tourist flow and the population of the region. The problem of concept development in the region is the lack of a unified approach in the definition of "municipal solid waste", as well as compliance with normative legal acts operating in the field of waste management. It attracts attention of scientists and the public because of the negative impact on all spheres of activity and tourist attractiveness of the Kaliningrad region. The number of tourists in connection with the launch of e-visa mechanism for foreigners is expected to be not less than $8 \%$ in comparison with record levels in $2018-1.52$ million people. The majority of tourists falls on the period from April to October. The maximum influx of tourists falls on the summer.

The problem of the organization of industrial processing is relevant in connection with necessity of reduction of volumes of burial in landfills. Unmanaged waste streams is a factor in the spread of countless diseases (Eurostat).

In each form of tourism, it is not tourism activities and developing tourism infrastructure that has a major impact on the natural environment. In the beautiful natural areas of pressing concern is the situation with waste, their removal and disposal. This is a problem especially for places with high tourist appeal. Solid waste adversely affects the tourist attractiveness of territories, water resources and shoreline. The waste management system, which operates in the region, does not serve the international and Russian regulations for the protection of the environment. In the region there is selective waste collection among the population. This is due to the lack of appropriate conditions and technical support. This is due to the lack of appropriate technical conditions and legislation.

The European experience shows that the main trend of solving the solid waste problem is a gradual transition from landfill to industrial processing (Nikogosov, 2010). The involvement of solid waste in the industrial processing largely removes the contradiction between a city with a large number of waste and the suburbs, where the waste must be placed (Antmann, Celik, Shi, Dai, 2012). By law, polygons are located outside of the city. The size of the sanitary protection zone from residential development to the boundaries of the landfill is $500 \mathrm{~m}$. In addition, the size of the sanitary protection zone can be specified when calculating gaseous emissions into the atmosphere. The zone boundaries are set by isoline 1 of the MPC, if it goes beyond the limits of the regulatory 
zone (SanPiN 2.1.7.1038-01 Hygienic requirements for the arrangement and maintenance of landfills for solid waste).

Technologies used for collection, storage and disposal of solid waste are outdated and inadequate given climatic conditions of the territory and recreational requirements (Nikogosov, 2010). To optimize the system of management of disposal of solid waste at the present time, it is necessary to apply advanced techniques and tools. In the Kaliningrad region, as in most other regions of Russia, there are no founding documents which can be used to control the system of waste management strategy and prospective scheme of waste disposal.

In the framework of the national project "Ecology" in 2019, the implementation of the Federal target program "Formation of an integrated system of municipal solid waste management" has started. The Kaliningrad Oblast, among 62 subjects of the Russian Federation, not only must proceed with its implementation, but also provide predictive estimates of the possible reduction of tariffs for the transportation of waste to the disposal site, disposal, processing, etc. According to the Ministry of Natural Resources and Ecology of the Russian Federation, this reduction can reach $30 \%$ of the previously approved values. For more successful implementation of the new program, it is planned to concentrate all the necessary permissions (from local schemes to the restoration of objects of accumulated damage), placing them in the introduction of the Ministry of Natural Resources, including waste collection among consumers, delivering them to places, and introduction of new technologies. Sustainable development of any natural areas is inextricably linked to the development of a system of solid waste management in the tourist area. Tourism is the most profitable and intensively developing branch of world economy. Responsible waste management helps in making tourism development sustainable. The accumulation of waste affects the environment, including pollution of soil, water and air.

With technological progress comes a large amount of waste, together with the problem of their disposal, including the tourism industry. The situational analysis of the sphere of solid waste management in the Kaliningrad region showed that the greatest obstacle to the transition of the region towards sustainable development is not only a large number of landfills that are outdated, but the lack of infrastructure for waste recycling. The methodological basis of the work is devoted to problems of assessment of economic damage from environmental pollution with household waste. The problem that is associated with the waste exists and needs solving. As shown by the analysis of the works regarding aspects of recycling different types of waste, to use foreign models of recycling is currently not possible.

However, both central and regional ministries and agencies have noted the problems and risks that can meet regional artists. To them, the problem includes in particular poorly developed territorial plans for waste management, excessive rates, tightening of the transition to a new stage of reform, lack of logistics transport waste to disposal sites etc. 


\section{Assessment of solid waste landfills in the Kaliningrad region}

At the moment there are no capabilities to maximize recycling of accumulated waste or optimal, environmentally friendly ways to remove them. Planned activities should become an effective tool for the local population, tourist organizations, which carry out their activities, public and private utility services.

The Kaliningrad region also had problems related to the implementation of the reform. Each year, the region is formed of 600 thousand tons of solid waste. About $85 \%$ of them are placed in municipal landfills.

In the Kaliningrad region, because of the pollution of municipal and industrial waste, there is a poor quality of drinking water and air, which adversely affects the health of the population. The main problem is obsolete and overloaded waste landfills (tab. 1).

Table 1. List of landfills/dumps of household waste in the Kaliningrad region (with the right collection, treatment, recycling, disposal of waste $\mathrm{I}-\mathrm{V}$ hazard classes)

\begin{tabular}{|l|c|c|}
\hline \multicolumn{1}{|c|}{ The name and location of the object } & Name of legal entity & Year of inclusion in Rosreestr \\
\hline $\begin{array}{l}\text { Polygon in Barsukovka settlement, Neman district } \\
\text { without waste sorting complex }\end{array}$ & SE CO «ESOO» & 2014 \\
\hline $\begin{array}{l}\text { Polygon Zhavoronkovo in Gusev urban district } \\
\text { with a waste sorting complex }\end{array}$ & $\begin{array}{c}\text { JSCMUP «Garbage Disposal» } \\
\text { of the municipality } \\
\text { «Gusev urban district» }\end{array}$ & 2014 \\
\hline $\begin{array}{l}\text { Polygon El'nyaky in Gvardeisk city district } \\
\text { without the waste sorting complex }\end{array}$ & MUP «Rainbow» & 2017 \\
\hline $\begin{array}{l}\text { Polygon in Kruglovo settlement of Zelenograd city } \\
\text { district without waste sorting complex }\end{array}$ & CO «ESOO» & 2018 \\
\hline
\end{tabular}

Source: own elaboration.

Was assessed the total volume of waste production and consumption in the Kaliningrad region. As a source of information to estimate the volume of waste production and consumption and their perspective changes, different sources were used:

1. Data of Federal statistical observation No. 2-TP (wastes).

2. The regional cadastre of waste production and consumption of the Kaliningrad region.

3. Data of administrations of municipal unions of the Kaliningrad region and specialized organizations carrying out activities on waste management on the territory of the Kaliningrad region.

4. Data of the Kaliningrad regional customs.

According to statistics, one person (tourist) per day, on average, leaves up to $3 \mathrm{~kg}$ of garbage. The lack of a civilized system of regular collection and removal of waste and the household waste disposal leads to the fact that the coast, beaches and vacation spots look like garbage site, which leads to irretrievable loss of tourist attractiveness. At the moment, there are 4 landfills (polygons) in the Kaliningrad region with the right to collect, process, utilize, dispose waste of $\mathrm{I}-\mathrm{V}$ hazard classes and there is only one of them with a sorting complex, which is scheduled to be launched in 2020. Studies of morphological composition of solid waste carried out in the Kaliningrad region in 
different periods showed some differences with the data used in the Russian Federation as reference. It marked the high content of plastics. The analysis of the situation showed that the normativelegal support of the waste management system is inefficient. It does not correspond to modern science on the rational use of raw and material resources. The increasing amount of solid waste statistics waste is not enough, or not done at all, and it does not take into account the norms of international law in the field of waste management, which is not considered positive law enforcement practice abroad. Because the landfill is farther removed from the city and infinitely the arm of the removal of solid waste could not be increased, it becomes highly relevant for industrial processing of household waste that addresses the combined issues of clearance, removal and disposal of solid waste, and represents a fundamental way of solving this problem.

On the map given in the article (fig. 1), we can see the placement of the MSW landfills in the Kaliningrad region. The assessment of the quantity of municipal solid waste coincides with the major municipalities - leaders on the volume of solid waste - which are simultaneously large tourist centers. These include Kaliningrad, Zelenogradsk, Chernyakhovsk, Gusev, Sovetsk (fig. 1). Due to the adverse environmental situation, the largest MSW landfill in the region was closed in the area of baltiyskoe highway (Kosmodemyanskaya settlement) of the municipal unitary enterprise "Chistota" and the landfill in the city of Mamonovo. The project documentation for reclamation was transferred for a state environmental expertise.

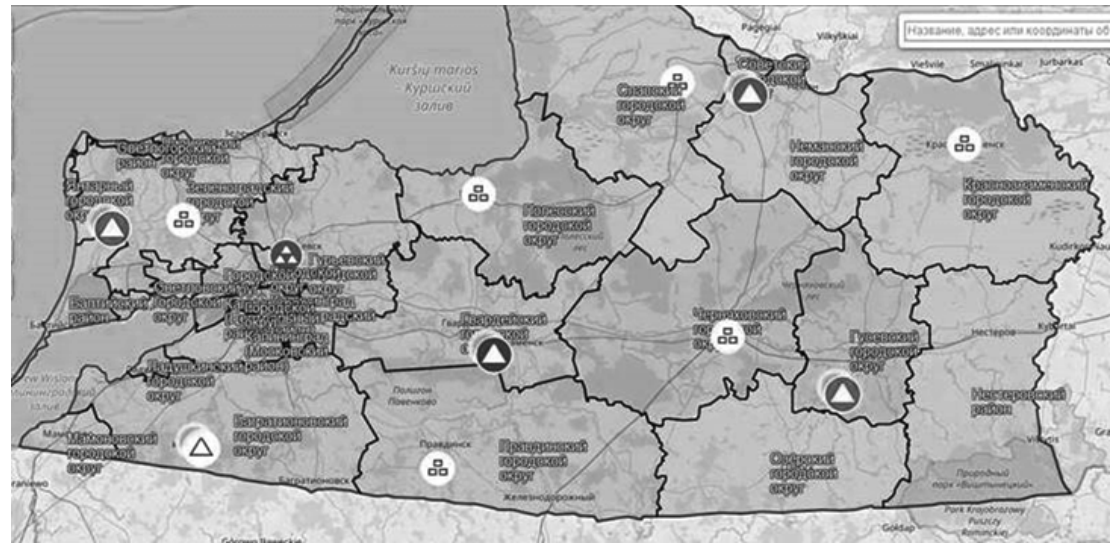

Figure 1. The location of the main landfills in the Kaliningrad region

Source: own elaboration

After closing the landfill near the village, Kruglovo became the main site for the storage of solid waste. But since it started working in 1977, the accumulated waste has exceeded the allowable limit. Here are not met even the basic requirements of environmental safety, there are no fences, and no need of protection. Near the village of Sychevo is a site owned by the regional government, where it is possible to create a new landfill that meets all requirements. But it needs considerable 
funds and the establishment of cluster for recycling in the village of Kornevo, where attracting investors is not yet possible.

On the ground "Zhavoronkova" functions a sorting line; the range "Barsukovo" was built relatively recently, consistent with modern environmental standards. The amount of waste there are relatively small. Analyzing data on utilization and neutralization of wastes leads to the conclusion that the proportion of neutralized waste was significantly reduced. In the region for 2018, 4 thousand tons of secondary raw materials were selected from waste, and 436,532 thousand tons of waste were placed in landfills. Less than $1 \%$ of the total amount was sent for recycling, and most of it is stored in landfills.

\section{The draft territorial plans for waste management}

In 2017, there was approved a procedure for collection of municipal solid wastes in the Kaliningrad region (State report "The status and environment of the Russian Federation in 2019"). For the period up to 2025, the project developed territorial plans for waste management (Territorial scheme of waste management in the Kaliningrad region) and created its e-model ("On approval of the procedure of collection of municipal solid waste"). Its purpose is to minimize the harmful effects of toxic waste. On the basis of mapping of the region, the support is located in a point of waste management system - the infrastructure associated with each other and visualizing the logistics of waste transport in the region.

The e-model allows to evaluate the economic efficiency of transportation of waste to justify the choice between their transportation and the construction of new facilities for the storage or processing of MSW, to systematize the material on the area of responsibility of the regional operator for the calculation of the tariff for transportation of MSW. The beginning of the reform for the first time in the history of the Russian Federation provides for separate collection, waste sorting and further recycling. However, the infrastructure of recycling in the regions is poorly developed. The organization for the collection, disposal and recycling certain types of waste is not sufficiently loaded. There is no centralized waste collection system. According to Kaliningrad Regional Environmental Prosecutor's Office, illegal waste disposal stands for $30 \%$ of the total number of revealed violations of environmental legislation. There are about 5 thousand violations of the legislation of waste management and other environmental management standards (State report "On condition and protection of the environment in 2019").

Environmental legislation of the Russian Federation is spread out over many laws and regulations. Separate provisions related to the treatment of solid wastes are contained in Land, Water, Forest, Criminal Codes of the Russian Federation and other federal laws. They were repeatedly amended in law No. 503-FZ - "On wastes of production and consumption". Fragmented regulations define the authority of the RF subjects and local authorities in this sphere, the requirements for territorial schemes of the treatment of MSW and to the sites of waste accumulation.

Based on the latest edition of the law "On wastes of production and consumption in the Kaliningrad region", (The law "On wastes of production and...") the government of the region 
approved the procedure for the collection of solid waste, including separating the garbage (The resolution of the Government of the Kaliningrad region). In the new version of the law appeared first clarified concepts such as "collection of waste", "waste accumulation", payment and spending of environmental fee. Clarified were the requirements for regional operators for dealing with MSW to the contracts, activities, operators, tariffs and investment programs. The law first sets out requirements in relation to the collection of various types of waste (bulky, electronic, mercury) in order to prevent their harmful effects and ensure the use of practical components contained in the waste. The law has also prohibited unauthorized placement of all types of wastes and their collection without special equipment and processing documents of the established sample. Separate collection should be implemented gradually in all localities with the installation of special containers. However, necessary adjustments and appropriate amendments of the federal law "On wastes of production and consumption" (version of 1998) must be made in order to eliminate ambiguity in terminology and strengthen the control over movements of hazardous wastes and their disposal. Instead of collecting and processing waste in the federal legislation, there is still proposed disposal by burial in landfills. This solution has not fixed the problem of the responsibility of producers for recycling their products at the end of life cycle. There is no differentiation in the regulation of waste management with regard to their impact on human health and natural ecosystems.

\section{Conclusions}

1. Based on the composition of waste and a large amount of plastic control schemes at all stages (including industrial processing), there is a need for a combination of technological operations of separation of wastes into individual fractions and components and their subsequent optimal processing methods.

2. It is necessary to minimize the amount of solid waste sent to landfills. Create waste sorting complexes based on separate collection in the residential and non-residential sectors of the city, taking into account the trends of reducing the amount of waste (sustainable consumption).

Original position concept identifies the goals and objectives:

1. Reduction of volume and mass of waste dumped with the prospect of transition to wastefree production.

2. Waste management (hygienic treatment, the elimination of harmful components, etc.).

3. Recycling of wastes (material and heat, with the possibility of obtaining and use of energy, production of new types of products).

4. The use of aerobic fermentation (the organic portion of the wastes by microorganisms).

The Kaliningrad region, in the light of European experience, is an opportunity to solve the issue. It is necessary to solve the problem of solid and liquid waste in all municipalities simultaneously. It requires an integrated approach at the scale of region, taking into account the specifics of each municipality. The greening of tourism plays an important role in ensuring the safety of tourist routes, improve the quality and competitiveness of tourism products and disclosure 
of socio-economic potential of tourism in the region. The new concept of social development, which rely on the cooperation of states in dealing with the problems of household waste disposal, is required and will lead to the solution of intractable problems. Optimal solution to the problem may be connected with optimization of the system of collection and disposal of solid waste, construction of plants for complex processing with the use of advanced technologies (with a long-term strategy of transition from landfill to their industrial processing).

\section{References}

Antmann, E.D., Celik, N., Shi, X., Dai, Y. (2012). Simulation-based optimization of solid waste management and recycling programs. IIE 62nd Ann. Conf. \& Ex., 759-768.

Eurostat. Retrieved from: http://epp.eurostat.ec.europa.eu/portal/page/portal/eurostat/home/. (5.09.2019).

Nikogosov, H.N. (2010). Actual problems of sanitary cleaning of cities from solid waste. Clean City, 2 (50), 9-11.

Territorial scheme of waste management in the Kaliningrad region (as amended by 2018-2019) (11.09.2019).

The law "On wastes of production and consumption in the Kaliningrad region" from 26.03.2018 No. 150 (7.08.2019).

The Ministry of natural resources and ecology of the Russian Federation. State report "The status and environment of the Russian Federation in 2019”. Retrieved from: http://www.mnr.gov.ru/ (15.09.2019).

The Ministry of natural resources and environment of Kaliningrad region. State report "On condition and protection of the environment in 2019”. Retrieved from: https://minprirody.gov39.EN/deyatelnost/territorialnaya-skhemaobrashcheniya-s otkhodami/ (24.08.2019).

The resolution of the Government of the Kaliningrad region "On approval of the procedure of collection of municipal solid waste" from 28.09.2017, No. 519.

\section{KONCEPCJA GOSPODARKI ODPADAMI STAŁYMI W PRZEMYŚLE TURYSTYCZNYM W OBWODZIE KALININGRADZKIM}

SŁOWA KLUCZOWE ABSTRAKT gospodarka odpadami stałymi, przetwarzanie odpadów, przemysł turystyczny, ekologizacja turystyki, Obwód Kaliningradzki

W artykule przedstawiono przegląd zagadnień związanych z przetwarzaniem komunalnych odpadów stałych w przemyśle turystycznym Obwodu Kaliningradzkiego oraz analizę problemów środowiskowych związanych z ich utylizacją. Celem artykułu jest ukazanie cech współczesnego stanu gospodarki odpadami i jej wpływu na atrakcyjność turystyczną regionu. Autor ujawnia skład materiałowy, klasy zagrożenia i przestrzenny rozkład odpadów z gospodarstw domowych oraz określa ich związek z dzielnicami miejskimi i ośrodkami turystycznymi regionu. W artykule przedstawiono mechanizm gospodarowania odpadami stałymi w branży turystycznej Obwodu Kaliningradzkiego na podstawie analizy sytuacji ekologicznej oraz możliwych sposobów wykorzystania możliwości zewnętrznych z uwzględnieniem charakteru lokalizacji ośrodków turystycznych i sytuacji regionu. Obwód Kaliningradzki ma pozycję eksklawy i jest oddzielony od głównego terytorium kraju, co stanowi duży problem pod względem usuwania odpadów. 
Strategiczne planowanie gospodarki odpadami opiera się na zestawie przepisów i procedur, których stosowanie zapewni szybką reakcję na wzrost ilości odpadów, w tym tworzyw sztucznych. Aby rozwiązać ten problem, autor proponuje wykorzystanie pozytywnych doświadczeń zagranicznych, biorąc pod uwagę krajowe ramy regulacyjne. Analiza sytuacji w zakresie wzajemnego oddziaływania turystyki i stanu ekologicznego stałych odpadów komunalnych w regionie pozwala na sformułowanie rekomendacji dla ekologizacji turystyki jako czynnika rozwoju regionalnego w oparciu o trendy w światowej praktyce problematyki odpadów i wymogi nowoczesności. 